\title{
ANALISIS PAJAK REKLAME DALAM UPAYA MENINGKATKAN PAD DI KABUPATEN SAROLANGUN
}

\author{
Ahmad Soleh \\ Dosen Tetap Universitas Muhammadiyah Jambi \\ mas.soleh@yahoo.com
}

\section{Ringkasan}

Penelitian ingin menganalisis mengenai: (1) Potensi penerimaan pajak reklame dan; (2) mengidentifikasi permasalahan-permasalahan tentang penerimaan pajak reklame di Kabupaten Sarolangun. Metode analisis yang digunakan dalam penelitian ini adalah deskriptif kualitatif dan kuantitatif dengan menggunakan data sekunder. Dari hasil analisis menunjukkan bahwa secara rata-rata: capaian realisasi penerimaan pajak reklame terhadap target penerimaan pajak reklame selama tahun 2010-2014 sebesar 118,3 persen; elastisitas potensi penerimaan pajak reklame sebesar 8,78 persen; tingkat efektifitas penerimaan pajak reklame di Kabupaten Sarolangun adalah sangat efektif; kontribusi realisasi penerimaan pajak reklame terhadap pendapatan asli daerah sebesar 0,887 persen; kontribusi pajak reklame terhadap pajak daerah di Kabupaten Sarolangun sebesar 3,98 persen; laju pertumbuhan target dan pajak reklame di Kabupaten Sarolangun masing masing sebesar 34,77 persen dan 68,60 persen. Sehingga dapat disimpulkan bahwa potensi penerimaan pajak reklame di Kabupaten Sarolangun masih dapat ditingkatkan kembali.

Kata kunci: Potensi, efektivitas, kontribusi, elastisitas

\section{PENDAHULUAN}

Pelimpahan wewenang dalam pengelolaan keuangan dari pemerintah pusat kepada pemerintah daerah telah diikuti pula dengan penyerahan kewenangan menggali potensi, penerimaan dan pengalokasiannya yang dilaksanakan melalui kebijakan desentralisasi fiskal. Dalam konteks pemerataan kemampuan keuangan daerah, sebagai upaya pemerataan tersebut pemerintah pusat mengeluarkan kebijakan melaui dana perimbangan. Kebijakan tersebut adalah bentuk dari distribusi sumberdaya keuangan (financial sharing) yang bertujuan memberdayakan dan meningkatkan kemampuan ekonomi daerah, mengurangi kesenjangan antar daerah dan untuk menciptakan sistem pembiayaan yang adil, proporsional, rasional serta kepastian sumber keuangan yang berasal dari wilayah yang bersangkutan.

Dengan diberlakukannya otonomi daerah, tentunya semua daerah dituntut untuk mandiri dan mengurangi tingkat ketergantungannya terhadap pemerintah pusat dan memberikan kebebasan kepada daerah untuk menyusun sendiri program-program kerja dan anggaran sesuai dengan kebutuhan dan kapasitas daerah. Dengan harapan pemerintah daerah akan lebih efektif, efisian dan mampu meningkatkan pelayanan publik, membangun sarana perekonomian serta menciptakan lapangan pekerjaan yang lebih bangyak lagi bagi masyarakat didaerah. 
Salah satu wujud dari pelaksanaan desentralisasi fiskal adalah pemberian sumber-sumber penerimaan bagi daerah yang dapat digali dan digunakan sendiri sesuai dengan potensinya masing-masing. Sumber-sumber penerimaan tersebut dapat berupa pajak daerah atau retribusi daerah. Sesuai dengan amanat Undang-Undang Dasar 1945, setiap pembebanan pada masyarakat baik berupa pajak maupun retribusi harus diatur dengan undang-undang. UndangUndang Republik Indonesia Nomor 33 Tahun 2004 pada pasal 5 menjelaskan sumber-sumber penerimaan daerah berasal dari berbagai sumber/jenis antara lain: Pendapatan Asli Daerah (PAD), dana perimbangan, lain-lain pendapatan asli daerah yang sah.

Pendapatan asli daerah (revenue from own sources) merupakan pendapatan daerah yang bersumber dari hasil pajak daerah, hasil retribusi daerah, hasil pengelolaan kekayaan daerah yang dipisahkan, dan lain-lain pendapatan asli daerah yang sah yang bertujuan untuk memberikan keleluasaan kepada daerah dalam menggali pendanaan dalam pelaksanaan otonomi daerah sebagai perwujudan asas desentralisasi.

Penetapan jenis pajak dan retribusi didasarkan pertimbangan bahwa jenis pajak dan retribusi tersebut secara umum dipungut oleh hampir semua daerah dan merupakan jenis pungutan yang secara teoritis dan praktis merupakan pungutan yang baik. Selain jenis pajak dan retribusi tersebut, daerah juga diberikan kewenangan untuk memungut jenis pajak dan retribusi lainnya sesuai kriteria-kriteria tertentu yang ditetapkan dalam undang-undang.

Sebagaimana daerah lainnya di Indonesia, sumber-sumber pendapatan asli daerah Kabupaten Sarolangun yang utama diperoleh dari pajak dan retribusi daerah. Pajak reklame adalah salah satu jenis pajak yang mampu menjadikan sumber PAD dalam mendukung penyelenggaraan pemerintah dan pembangunan daerah yang pada akhirnya akan mampu meningkatkan kesejahteraan masyarakat. Dengan demikian, pajak reklame diharapkan menjadi potensi PAD yang akan memberikan kontribusi yang signifikan terhadap Anggaran Pendapatan dan Belanja Daerah (APBD) Kabupaten Sarolangun.

Namun dalam proses pelaksanaannya banyak menemui kendala-kendala seperti wajib pajak yang menunggak pembayaran, wajib pajak yang mangkir, tidak patuh dengan batas waktu yang diberikan dan rendahnya kesadaran masyarakat. sehingga perlu dilakukan upaya untuk meggali permasalahan guna mengoptimalkan penerimaan pajak reklame ini. Berdasarkan uraian diatas maka penelitian ini bertujuan untuk menganalisis: (1) Potensi penerimaan pajak reklame di Kabupaten Sarolangun dan; (2) mengidentifikasi permasalahan-permasalahan tentang penerimaan pajak reklame di Kabupaten Sarolangun. 


\section{TINJAUAN PUSTAKA}

\section{Pendapatan Asli Daerah}

Pendapatan asli daerah berdasarkan Undang-Undang Nomor 33 Tahun 2004 tentang Perimbangan Keuangan Antara Pusat dan Daerah Pasal/angka 18 bahwa "Pendapatan asli daerah, selanjutnya disebut PAD adalah pendapatan yang diperoleh daerah yang dipungut berdasarkan peraturan daerah sesuai dengan peraturan perundang-undangan". Sumber pendapatan daerah terdiri dari: Pajak Daerah, retribusi daerah, pengelolaan kekayaan daerah yang dipisahkan, lain lain pendapatan yang sah.

\section{Konsep Pajak}

Pajak adalah suatu pungutan yang merupakan hak prerogatif pemerintah, pungutan tersebut didasarkan pada undang-undang, pemungutannya dapat dipaksakan kepada subjek pajak untuk mana tidak ada balas jasa yang langsung dapat ditunjukkan penggunaannya (Mangkoesoebroto, 1998).

Menurut Smeets dalam bukunya De Economische Betekenis der Belastingen, 1951 (dalam Suandy, 2008), mengatakan: Pajak adalah prestasi kepada pemerintah yang terutang melalui norma-norma umum, dan yang dapat dipaksakan, tanpa ada kalanya kontraprestasi yang dapat ditunjukkan dalam hal yang individual, maksudnya adalah untuk membiayai pengeluaran pemerintah.

Sedangkan Rochmad Soemitro menyatakan, pajak adalah iuran kepada kas negara berdasarkan undang-undang (yang dapat dipaksakan) dengan tidak mendapat cara timbal balik (kontra prestasi), yang langsung dapat ditujukan dan digunakan untuk membayar pengeluaran umum (dalam Mardiasmo, 2003).

\section{Pajak Daerah}

Menurut UU Nomor 34 Tahun 2000 tentang perubahan atas UU Nomor 18 tahun 1997 tentang Pajak daerah dan Retribusi Daerah. "Pajak daerah adalah iuran wajib yang dialihkan oleh orang pribadi dan badan kepada daerah tanpa imbala langsung yang seimbang, yang dapat dipaksakan berdasarkan peraturan perundang-undangan yang berlaku, yang digunakan untuk membiayai penyelenggaraan pemerintahan daerah dan pembangunan daerah".

Pajak daerah adalah pajak yang dipungut oleh pemerintah daerah (propinsi, kota madya, kabupaten), dan hasilnya digunakan untuk membiayai keperluan ruamh tangga daerah pada umumnya. pajak daerah ditingkat propinsi dikelola oleh dinas pendapatan daerah Tk.I, sedangkan ditingkat kabupaten atau kota madya dikelola oleh dinas pendapatan daerah tingkat 
II. Menurut UU.No. 18 tahun 1997, tentang "pajak daerah dan retribusi Daerah", sebagaimana telah diubah dengan UU NO.34 tahun 2000.

\section{Pajak Reklame}

Pajak reklame adalah iuran wajib yang dikenakan pada pengguna reklame. Reklame adalah benda, alat perbuatan atau media yang menurut bentuk susunan dan corak ragamnya untuk tujuan komersial dipergunakan untuk memperkenalkan, menganjurkan atau memujikan suatu barang, jasa atau orang, ataupun untuk menarik perhatian umum kepada suatu barang atau jasa, orang yang ditempatkan atau dapat dilihat, dibaca atau didengar dari suatu tempat oleh umum, kecuali yang dilakukan oleh Pemerintah dan pengecualian lainnya sesuai dengan peraturan yang berlaku (Siahaan, 2005).

\section{METODOLOGI PENELITIAN}

Metode analisis yang digunakan penelitian ini adalah metode deskriptif kuantitatif dan kualitatif. Yaitu metode yang menjelaskan dan menerangkan hasil analisis data melalui pengukuran obyektif dan analisis numerikal (Maradalis, 2003).

\section{Sumber Data}

Data yang digunakan dalam penelitian ini adalah data sekunder time series yang berasal dari DPPKAD Kabupaten Sarolangun dari tahun 2010 sampai 2014.

\section{Alat analisis data}

\section{Perhitungan Potensi Penerimaan Reklame}

Dalam menghitung potensi penerimaan Pajak Reklame dihitung dengan model sebagai berikut: $\quad$ Take Base $=$ Jumlah Sewa Pajak Reklame di Daerah j Selanjutnya setelah diperoleh hasil basis pajaknya, maka langkah kedua yang perlu diketahui adalah potensi penerimaan Pajak Reklame dengn menggunakan rumus sebagai berikut :

Potensi PR= Basis Reklame X Tarif Pajak Reklame

Semakin besar hasilnya, maka semakin besar potensi penerimaan yang bakal diterima sebagai penerimaan Pajak reklame.

\section{Efektivitas Pajak Reklame}

Menurut Devas (1989), efektivitas yaitu hubungan antara output dan tujuan atau dapat juga dikatakan merupakan ukuran seberapa jauh tingkat output tertentu, kebijakan dan prosedurdari organisasi. Efektivitas juga berhubungan dengan derajat keberhasilan suatu operasi pada sektor publik sehingga suatu kegiatan dikatakan efektif jika kegiatan tersebut 
mempunyai pengaruh besar terhadap kemampuan menyediakan pelayanan masyarakat yang merupakan sasaran yang telah ditentukan (dalam Simanjuntak,2001).

Adapun cara untuk mengukur efektivitas pemungutan pajak reklame adalah sebagai berikut :

$$
\text { Efektivitas }=\frac{\text { Realisasi Penerimaan Pa jak Reklame }}{\text { Potensi Penerimaan Pajak Reklame }} \times 100 \%
$$

Tujuan adari efektivitas adalah untuk mengukur rasio keberhasilan, semakin besar rasio maka semakin efektif, standar minimal rasio keberhasilan adalah 100 persen atau 1 (satu) dimana realisasi sama dengan target yang telah ditentukan. Rasio dibawah standar minimal keberhasilan dapat dikatakan tidak efektf. Selama ini belum ada ukuran baku mengenai kategori efektifitas, ukuran efektifitas biasanya dinyatakan secara kualitatif dalam bentuk pernyataan saja (judgement). Dalam penelitian ini tingkat efektifitas dapat digolongkan kedalam beberapa kategori yaitu:

1. Hasil perbandingan tingkat pencapaian diatas 100 persen berarti sangat efektif.

2. Hasil perbandingan tingkat pencapaian 100 persen berarti efektif.

3. Hasil perbandingan tingkat pencapaian dibawah 100 persen berarti tidak efektif.

\section{Pengukuran Daya Pajak Reklame (Tax Effort)}

Daya Pajak Reklame (Tax Effort) adalah rasio antara realisasi penerimaan Pajak reklame dengan kapasitas atau kemampuan bayar pajak disuatu daerah. Salah satu indikator yang dapat digunakan untuk mengetahui kemampuan membayar masyarakat adalah Produk Domestik Regional Bruto, dengan formula sebagai berikut :

Daya Pajak $=\frac{\text { Penerimaan Pajak Reklame }}{(\text { PDRB }) t} \times 100 \%$

Jika PDRB suatu daerah meningkat maka kemampuan masyarakat disuatu daerah dalam membayar (ability to pay) pajak juga akan meningkat.

\section{HASIL PENELITIAN}

\section{Analisis Pajak Reklame di Kabupaten Sarolangun}

\section{- Analisis Target dan Realisasi Pajak Reklame di Kabupaten Sarolangun}

Baik tidaknya kinerja suatu kegiatan ditentukan oleh tinggi atau rendahnya dari hasil kinerja tersebut. Dalam menentukannya maka digunakan indikator atau yang disebut dengan target. Target sendiri diartikan sebagai penetapan atau sasaran batas ketentuan yang sudah ditetapkan dan harus dicapai dalam waktu tertentu. Dengan demikian akan terlihat bagaimana 
dan sampai berapa besar realisasinya yang tercapai apakah sesuai dengan target yang ditetapkan atau tidak.

Tabel.1. Jumlah target dan realisasi penerimaan pajak reklame di Kabupaten Sarolangun tahun 2010-2014

\begin{tabular}{|c|c|c|c|}
\hline \multirow{2}{*}{ Tahun } & \multicolumn{3}{|c|}{ Pajak Reklame (Papan/Biilboard/Vidiotron/Megatron/Tetap) } \\
\cline { 2 - 4 } 2010 & Target & Realisasi & Capaian (\%) \\
\cline { 2 - 4 } & $93.046 .760,00$ & $160.000 .000,00$ & 120,65 \\
\hline 2011 & $200.000 .000,00$ & $214.570 .234,00$ & 107,29 \\
\hline 2012 & $320.000 .000,00$ & $253.220 .152,00$ & 79,13 \\
\hline 2013 & $334.000 .000,00$ & $380.366 .300,00$ & 133,88 \\
\hline 2014 & $500.000 .000,00$ & $667.817 .000,00$ & 133,56 \\
\hline
\end{tabular}

Sumber : DPKAD Kabupaten Sarolangun

Dari data diatas terlihat peningkatan yang signifikan Secara umum pajak reklame mengalami peningkatan secara signifikan baik dilihat dari penetapan target maupun realisasi penerimaan yang dicapai. Peningkatan penetapan target ini merupakan proses rencana peningkatan penerimaan Pajak Reklame dimasa yang akan datang, yang ditetapkan oleh pemerintah. Penetapan target tersebut dilakukan sebagai indikator yang digunakan dalam mengukur capaian kinerja yang harus dicapai. Dan jika dilihat dari besarnya realisasi penerimaan yang diterima, secara umum penerimaan pajak reklame di Kabupaten Sarolangun sudah melebihi dari target yang ditetapkan atau dapat dikatakan kinerjanya sangat baik dengan rata -rata capaian kinerja realisasi penerimaan pajak reklame sebesar 118,3 persen.

\section{- Potensi penerimaan pajak reklame di Kabubapten Sarolangun}

Potensi merupakan kemampuan yang memungkinkan untuk dikembangkan atau dapat pula diartikan sebagai kekuatan, daya dan kesanggupan. Dalam hal ini potensi pajak reklame adalah kemampuan, daya, kekuatan dan kesanggupan yang memungkinkan dapat dikembangkan dalam rangka meningkatkan penerimaan pajak reklame. Model yang digunakan dalam menghitung potensi pajak adalah model elastisitas. Model elastisitas ini merupakan model yang membandingkan perubahan proporsional antara suatu variabel dengan variabel lainnya. Elastisitas juga bisa digunakan untuk mengukur seberapa besar kepekaan atau reaksi konsumen terhadap perubahan harga. Dengan diketahuinya besaran nilai elastisitasnya maka dengan mudah kita dapat menentukan seberapa besar potensinya. 
Tabel.2. Hasil perhitungan besarnya elastisitas penerimaan pajak reklame di Kabupaten Sarolangun selama tahun 2010-2014.

\begin{tabular}{|c|c|c|c|}
\hline Tahun & $\begin{array}{c}\text { Laju Pertumbuhan } \\
\text { Ekonomi di } \\
\text { Kab.Sarolangun } \\
\text { (dalam \%) }\end{array}$ & $\begin{array}{c}\text { Pertumbuhan Penerimaan/ } \\
\text { Realisasi Pajak Reklame di } \\
\text { Kab.Sarolangun } \\
\text { (Dalam \%) }\end{array}$ & $\begin{array}{c}\text { Elastisitas/ Potensi } \\
\text { Penerimaan Pajak Reklame } \\
\text { di Kabupaten Sarolangun } \\
\text { (Dalam \%) }\end{array}$ \\
\hline 2010 & 8,2 & 130,60 & 15,93 \\
\hline 2011 & 8,7 & 18,01 & 2,07 \\
\hline 2012 & 7,8 & 50,21 & 6,44 \\
\hline 2013 & 7,5 & 75,57 & 10,08 \\
\hline 2014 & 7,3 & 68,60 & 9,40 \\
\hline Rata-rata & 7,90 & 68,60 & 8,78 \\
\hline
\end{tabular}

Sumber: Data diolah

Hasil analisis menunjukkan secara rata-rata elastisitas pajak reklame terhadap pertumbuhan ekonomi di Kabupaten Sarolangun sebesar 8,78 persen. Artinya potensi penerimaan pajak reklame rata-rata sebesar 8,78 kali pertumbuhan ekonomi di Kabupaten Sarolangun. Jadi setiap terjadi pertumbuhan ekonomi sebesar 1 persen akan meningkatkan penerimaan pajak reklame sebesar 8,78 persen.

Demikian juga yang terjadi pada tahun 2010 dengan nilai elastisitanya sebesar 15,93 persen, dan pada tahun 2011 dengan nilai elastisitasnya hanya sebesar 2,07 persen saja. Tinggi atau rendahnya elastisitas penerimaan pajak reklame yang ada dipengaruhi oleh rendahnya pertumbuhan penerimaan pajak reklame yang terjadi pada tahun tersebut..

Dengan diketahuinya rata-rata pertumbuhan ekonomi di Kabupaten Sarolangun sebesar 7,9 persen bertahun dan dan rata-rata nilai elastisitas sebesar 8,78. Maka dapat diprediksi pada tahun 2015 penerimaan pajak reklame di Kabupaten Sarolangun diperkirakan mengalami peningkatan sebesar 69,3 persen dari penerimaan yang ada. Artinya jika pemerintah ingin meningkatkan penerimaan dari pajak reklame maka penetapann targetnya juga harus dipertimbangkan berdasarkan dari potensi yang ada.

\section{- Efektivitas penerimaan pajak reklame di Kabupaten Sarolangun}

Dalam upaya meningkatkan penerimaan pajak reklame hal yang juga perlu dipertimbangkan adalah tingkat efektifitas. Efektivitas diartikan sebagai ukuran seberapa jauh tingkat keberhasilan suatu kegiatan atau proses realisasi penerimaan pajak reklame yang didasarkan pada potensi pajak reklame yang ada. Efektifitas juga digunakan seagai indikator dalam menentukan efektif tidaknya suatu kinerja SKPD, artinya semakin tinggi tingkat efektifitas maka semakin baik kinerjanya demikian juga sebaliknya semakin rendah tingkat efektifitas yang ada maka semakin rendah kinerja SKPD tersebut. 
Pada tabel dibawah ini terlihat bahwa secara rata-rata tingkat capaian efektifitas realisasi penerimaan pajak reklame terhadap target yang ditetapkan mencapai 118,2 persen dan masuk pada kategori sangat efektif.

Tabel.3. Tingkat capaian penerimaan pajak reklame di Kabupaten Sarolangun

\begin{tabular}{|c|c|c|c|}
\hline \multirow{2}{*}{ Tahun } & \multicolumn{3}{|c|}{ Pajak Reklame (Papan/Biilboard/Vidiotron/Megatron/Tetap) } \\
\cline { 2 - 4 } 2010 & Target & Realisasi & Capaian (\%) \\
\cline { 2 - 4 } & $160.000 .000,00$ & $193.046 .760,00$ & 120,65 \\
\hline 2011 & $200.000 .000,00$ & $214.570 .234,00$ & 107,29 \\
\hline 2012 & $320.000 .000,00$ & $253.220 .152,00$ & 79,13 \\
\hline 2013 & $334.000 .000,00$ & $380.366 .300,00$ & 113,88 \\
\hline 2014 & $500.000 .000,00$ & $667.817 .000,00$ & 133,56 \\
\hline
\end{tabular}

Sumber : Data diolah

Namun jika dilihat tingkat capaiannya pertahun, pada tahun 2012 capaian realisasi penerimaan pajak tidak mencapai terget (hanya 79,29 persen). Sementara capaian kinerja tertinggi pada tahun 2014 dengan tingkat capaian mencapai 133,56 persen dari target yang ditentukan.

\section{- Kontribusi target dan reasisasi penerimaan pajak Reklame terhadap pendapatan asli}

\section{daerah di Kabupaten Sarolangun}

Kontribusi pajak reklame terhadap pendapatan asli daerah Kabupaten Sarolangun masih sangat kecil dengan rata-rata kurang dari 1 persen. Dengan kontribusi terbesar pada tahun 2013 sebesar 1,215 persen sedangkan kontribusi terkecil terjadi pada tahun 2010 yang hanya sebesar 0,454 persen.

Tabel.4. Kontribusi penerimaan pajak reklame terhadap PAD Kabupaten Sarolangun

\begin{tabular}{|c|c|c|c|}
\hline Tahun & $\begin{array}{c}\text { Realisasi Pendapatan } \\
\text { Asli Daerah }\end{array}$ & $\begin{array}{c}\text { Realisasi penerimaan Pajak Reklame } \\
\text { (Papan/Biilboard/Vidiotron/ Megatron/ } \\
\text { Tetap) }\end{array}$ & $\begin{array}{c}\text { Kontribusi } \\
\text { (\%) }\end{array}$ \\
\hline 2010 & $20.475 .919 .595,31$ & $93.046 .760,00$ & 0,454 \\
\hline 2011 & $31.832 .232 .484,21$ & $214.570 .234,00$ & 0,674 \\
\hline 2012 & $28.007 .764 .671,40$ & $253.220 .152,00$ & 0,904 \\
\hline 2013 & $31.307 .858 .054,00$ & $380.366 .300,00$ & 1,215 \\
\hline 2014 & $56.310 .983 .395,40$ & $667.817 .000,00$ & 1,186 \\
\hline \multicolumn{2}{|r|}{ Rata-rata } & 0,887 \\
\hline
\end{tabular}

Sumber : Data diolah

Jika pemerintah ingin meningkatkan besarnya kontribusi penerimaan pajak reklame terhadap penerimaan daerah maka hal yang perlu dilakukan adalah dengan meningkatkan penerimaan pajak reklame. 


\section{- Kontribusi Penerimaan Pajak Reklame terhadap pajak daerah di Kabupaten Sarolangun}

Kemudian jika dilihat dari besarnya kontribusi pajak reklame terhadap penerimaan pajak daerah, Juga masih kecil dari data yang ada rata rata kontribusinya hanya 3,98 persen, seperti yang terlihat pada tabel dibawah ini:

Tabel.6. Besarnya kontribusi penerimaan pajak reklame terhadap penerimaan pajak daerah di Kabupaten Sarolangun tahun 2010 - 2014.

\begin{tabular}{|c|c|c|c|}
\hline Tahun & $\begin{array}{c}\text { Realisasi Penerimaan } \\
\text { Pajak Daerah }\end{array}$ & $\begin{array}{c}\text { Realisasi penerimaan Pajak Reklame } \\
\text { (Papan/Biilboard/Vidiotron/ } \\
\text { Megatron/Tetap) }\end{array}$ & $\begin{array}{c}\text { Kontribusi } \\
(\%)\end{array}$ \\
\hline 2010 & $3.670 .276 .146,00$ & $93.046 .760,00$ & 2,54 \\
\hline 2011 & $4.898 .266 .656,00$ & $214.570 .234,00$ & 4,38 \\
\hline 2012 & $7.185 .834 .569,00$ & $253.220 .152,00$ & 3,52 \\
\hline 2013 & $10.158 .779 .587,00$ & $380.366 .300,00$ & 3,74 \\
\hline 2014 & $11.643 .860 .442,25$ & $667.817 .000,00$ & 3,34 \\
\hline \multicolumn{2}{|l|}{ Rata-rata } & & 3,98 \\
\hline
\end{tabular}

Sumber: Data diolah

Rendahnya kontribusi penerimaan pajak reklame terhadap penerimaan pajak daerah ini dipengaruhi oleh beberapa faktor diantaranya faktor banyaknya industri (hasil olahan industri) yang siap dipasarkan, Jumlah penduduk, pendapatan masyarakat, dan potensi penerimaan yang ada. Beberapa faktor tersebut memberikan dampak yang cukup besar dalam penerimaan pajak reklame di kabupaten ini. Jumlah industri misalnya semakin banyak industri yang ingin memasarkan produknya didaerah tersebut maka semakin banya industri yang akan memasang reklame, demikian jumlah penduduknya semakin banyak pangsa pasar atau jumlah penduduk yang ada maka akan memacu proses pemasaran. Selain hal tersebut yang lebih penting adalah kemampuan atau daya beli masyarakat dimana semakin rendah daya beli masyarakat maka akan melemahkan para produsen untuk berlomba menawarkan produknya sehingga menimbulkan dampak penurunan penerimaan pajak reklame.

\section{- Laju Pertumbuhan Pajak Reklame di Kabupaten Sarolangun}

Laju pertumbuhan merupakan persentase pertambahan nilai yang didasarkan pada besarnya nilai tahun sebelumnya. Pertumbuhan juga merupakan salah satu indikator yang digunakan dalam menilai tingkat keberhasilah kinerja suatu kegiatan. Dari hasil pengolahan data dengan menggunakan model pertumbuhan maka diperoleh hasil seperti pada tabel dibawah ini. 
Tabel.7. Pertumbuhan target dan realisasi penerimaan pajak reklame di Kabupaten Sarolangun tahun 2010 - 2014

\begin{tabular}{|c|c|c|}
\hline Tahun & $\begin{array}{c}\text { Pertumbuhan target Pajak Reklame } \\
\text { (Papan/Biilboard/Vidiotron/Megatr } \\
\text { on/Tetap) (\%) }\end{array}$ & $\begin{array}{c}\text { Pertumbuhan realisasi penerimaan Pajak } \\
\text { Reklame (Papan/Biilboard/Vidiotron/ } \\
\text { Megatron/Tetap) (\%) }\end{array}$ \\
\hline 2010 & - & - \\
\hline 2011 & 25,00 & 130,60 \\
\hline 2012 & 60,00 & 18,01 \\
\hline 2013 & 4,38 & 50,21 \\
\hline 2014 & 49,70 & 75,57 \\
\hline Rerata & 34,77 & 68,60 \\
\hline
\end{tabular}

\section{Sumber : Data diolah}

Berdasarkan data diatas ada hal menarik yang perlu dikaji antara target yang ditetapkan pemerintah dalam meningkatkan penerimaan pajak reklame dengan pertumbuhan realisasi penerimaan pajak reklame yang ada. Secara rata-rata besarnya pertumbuhan target yang ditentukan hanya 50 persen dari pertumbuhan realisasi penerimaan pajak reklame yang ada. Mengapa ini terjadi?. Kondisi seperti ini memang sering terjadi pada instansi-instansi lain baik yang sejenis maupun yang tidak sejenis di Provinsi Jambi ini. Penetapan target selalu sangat rendah dibandingkan dengan potensi yang ada, hal ini dilakukan oleh instansi terkait guna mengantisipasi capaian hasil kinerja mereka agar tercapai target yang ditetapkan dan mengurangi beban kerja.

Jika kita bandingkan antara rata-rata pertumbuhan target pajak yang ditetapkan sebagai target kerja lebih kecil dibandingkan pertumbuhan yang terjadi pada realisasi pajak reklame. Ini didasarkan pada jumlah rata-rata pertumbuhan yang terjadi dari tahun 2010 sampai dengan tahun 2014. Dimana pertumbuhan target pada pajak reklame sebesar 34,77 persen sedangkan pertumbuhan realisasi pada pajak reklame sebesar 68,60 persen. Secara umum peningkatan yang terjadi merupakan tren positif dan sangat baik dalam proses peningkatan penerimaan, namun jika ingin meningkatkan lebih baik lagi maka pemerintah harus lebih giat dan taktis dalam melaksanakan pemungutan dan penentuan kebijakan sehingga akan mampu menciptakan nilai tambah yang lebih banyak lagi.

\section{Kendala yang dihadapi dalam pemungutan Pajak Reklame di Kabupaten Sarolangun.}

\section{a) Penyelenggaraan reklame belum sesuai dengan peraturan daerah yang berlaku}

Kurangnya kesadaran dari penyelenggara reklame sehingga pelaksanaan penataan pajak reklame terhambat. Berdasarkan pengamatan dilapangan masih sering terjadi hal-hal yang masih tidak sesuai dengan peraturan daerah yang ada seperti masalah pembongkaran reklame |setelah masa izin mereka habis. Ketidaktaatan penyelenggara reklame seperti ini 
disebabkan masih kurangnya pemahaman penyelenggara reklame untuk melaksanakan kewajibannya sesuai peraturan daerah yang berlaku. Tentunya kendala seperti ini sangat mengganggu jalannya kegiatan penataan yang dilaksanakan oleh pemerintah Kabupaten Sarolangun.

\section{b) Kendala dalam hal perizinan Reklame}

Kurangnya kesadaran penyelenggara reklame dalam mengurus izin pemasangan reklame, juga menjadi masalah yang sering terjadi dalam pelaksanaan penataan pajak reklame di Kabupaten Sarolangun. Hal ini dikarenakan kurang koordinasi antara penyelenggara reklame dan aparatur dalam hal mengelola dan mengaplikasikan kebijakan perizinan reklame.

\section{c) Kurangnya kesadaran dari wajib pajak untuk membayar pajak}

Kurangnya kesadaran wajib pajak dalam membayar apa yang menjadi kewajibannya. Kurangnya atau tidak adanya kesadaran masyarakat sebagai wajib pajak mengakibatkan timbulnya perlawanan sehingga mengakibatkan berkurangnya penerimaan kas daerah (APBD). Sesuai dengan Mardiasmo (2011) yang mana ada perlawanan pasif yang dilakukan wajib pajak reklame dimana enggan (pasif) dalam membayar pajak, mungkin dikarenakan sistem perpajakan yang sulit dipahami oleh wajib pajak reklame dan sistem kontrol yang tidak dapat dilaksanakan dengan baik.

\section{d) Wajib Pajak yang sulit untuk ditemui}

Kendala yang lain adalah wajib pajak yang melakukan penghindaran atau memang tidak ada di tempat atau lokasi atau berada diluar kota saat dilakukan penagihan. Sesuai dengan pendapat Mardiasmo (2011) dimana termasuk perlawanan aktif yang dilakukan wajib pajak reklame yang mana meliputi usaha dan perbuatan yang secara langsung ditujukan kepada fiskus dengan tujuan untuk menghindari pajak. Wajib pajak yang sulit ditemui ini bisa diartikan bahwa wajib pajak tersebut melakukan penghindaran pajak. Dalam temuan fakta di lapangan, seperti halnya Mardiasmo (2011) yang termasuk dalam perlawanan aktif dengan bentuk Tax Avoidance merupakan usaha wajib pajak reklame meringankan beban pajak dengan tidak melanggar undang-undang, jadi penghindaran pajak terjadi sebelum SKPD keluar. 
e) Belum terkoordinasi dengan baik antara SKPD dengan penyelenggara pajak.

Rendahnya koordinasi antara pengusaha penyedia tempat reklame dan pihak yang akan menjadikan titik lemah dalam proses identifikasi jumlah dan jenis pemasangan reklame yang ada, sehingga memungkinkan tidak kontrolnya proses pemungutan pajak.

\section{f) Belum maksimalnya penetapan Zonalisasi}

Jika penetapan zonalisasi tidak sesuai maka tarif pajak yang diberlakukan juga tidak sesuai sehingga tarif pajak yang dikenakan terhadap penyelenggara reklame lebih kecil dari yang seharusnya dikenakan.

\section{g) Lemahnya pengawasan Petugas/ PEMDA}

Masih rendahnya pengawasan oleh petugas pajak memberikan kesempatan kepada penyelenggara untuk tidak tertib dan membayar.

\section{h) Tingginya anggaran penertipan}

Masalah ini timbul karena kadang besarnya biaya yang dikeluarkan tidak sesuai dengan penerimaan yang diterima atau menyebabkan defisit anggaran.

Kebijakan yang dilakukan dalam meningkatkan Penerimaan Pajak Reklame di

\section{Kabupaten Sarolangun}

Upaya-upaya yang dilakukan Pemerintah Daerah dalam meningkatkan Penerimaan Pajak Reklame dapat dilakukan dengan:

1. Intensifikasi Pajak Reklame; Upaya itensifikasi ini dilakukan dengan menjalin hubungan kemitraan yang baik dengan subyek pajak. Selain itu Pemerintah juga dapat mengadakan penyuluhan memahami arti pentingnya membayar pajak serta mengevaluasi hasil pelaksanaan pemungutan agar masyarakat mempunyai keinginan dan kesadaran dalam membayar pajak.

2. Ekstensifikasi Pajak Reklame; Upaya ekstensifikasi dilakukan dengan cara:

a. Meningkatkan kemampuan aparat/petugas pelaksana pengawasan dan pemungutan pajak serta penambahan jumlah personil, pembentukan tim control, penambahan sarana dan prasarana yang dibutuhkan dalam menunjang kelancaran tugas.

b. Meningkatkan pengawasan oleh pemerintah daerah apabila dapat bekerjasama dengan seksi pendataan. Dalam pelaksanaan pendataan harus diperketat yang berpengaruh terhadap perubahan jumlah obyek pajak dan menyangkut perincian keseluruhan obyek pajak reklame. 
c. Mensosialisasikan dengan obyek dan sasaran serta melibatkan elemen masyarakat guna menumbuhkan kesadaran dan partisipasi baik dari penyelenggara maupun masyarakat secara luas dan menampung aspirasi/keluhan masyarakat dalam proeses pengawasan, keluhan sehingga dapat ditentukan kebijakan lebih lanjut.

d. Mempermudah dan memotong prosedur-prosedur dalam kepangurusan izin, pendaftaran, pembayaran serta memfasilitasi penyelenggara dalam proses pembayaran pajak reklame.

e. Mensosialisasikan aturan-aturan dan tarif pajak reklama kepada para pengusaha dan menerapkan Sistem pemberian Reword dan Panisment yang ketar bagi para penyelenggara yang membayar pajak tepat waktu dan pengusaha yang terlambat membayar pajak sampai dengan batas waktu yang ditentukan.

f. Mengadakan operasi yustisi bagi Wajib Pajak yang bandel dengan mendatangkan Sat Pol PP, polisi, DPPKA dan bagian hukum.

g. Meningkatkan koordinasi antar SKPD (Dispenda dengan Dinas tatakota) terkait penetapan letak, penetapan izin, penetapan tarif dan penetapan izin mendirikan bangunan (IMB)

\section{KESIMPULAN DAN SARAN}

\section{- Kesimpulan}

Berdasarkan pada analisis yang telah dilakukan dalam penelitian ini, maka dapat diambil kesimpulan sebagai berikut:

1. Rata-rata capaian realisasi penerimaan pajak reklame terhadap target penerimaan pajak reklame selama tahun 2010-2014 sebesar 118,3 persen dari target.

2. Rata-rata elastisitas potensi penerimaan pajak reklame secara rata-rata sebesar 8,78 persen.

3. Rata-rata tingkat efektifitas penerimaan pajak reklame di Kabupaten Sarolangun adalah sangat efektif.

4. Rata-rata kontribusi realisasi penerimaan pajak reklame terhadap pendapatan asli daerah sebesar 0,887 persen.

5. Rata-rata kontribusi pajak reklame terhadap pajak daerah di Kabupaten Sarolangun sebesar 3,98 persen.

6. Rata rata laju pertumbuhan target dan pajak reklame di Kabupaten Sarolangun masing masing sebesar 34,77 persen dan 68,60 persen. 


\section{- Saran}

Berdasarkan kesimpulan dan analisis diatas, maka disaran kebijakan yang dapat diambil adalah:

1. Dengan upaya intensifikasi; meningkatkan hubungan kemitraan, memberikan penyuluhan kepada para pengusaha dan penyelenggaran serta masyarakat sehingga meningkatkan kesadaran dalam membayar pajak.

2. Dengan upaya ekstensifikasi; dilakukan dengan cara peningkatan kemampuan aparatur, pengawasan, sosialisasi dan penerapan reward dan punishment, mempermudah prosedur perizinan, operasi yustiti, serta meningkatkan koordinasi antar SKPD dalam proses penetapan dan pemungutan pajak.

\section{DAFTAR PUSTAKA}

Yani, A. (2004). Hubungan Keuangan antara pemerintah dan daerah di Indonesia Edisi Kedua. Raja Grafindo Persada.

BKP2D. (2011). Analisis Penata usahaan Retribusi Daerah. Pemerintah Kabupaten Sarolangun.

Bratakusuma., Dedi, S., \& Solihin, D. (2001). Otonomi Pemerintah Daerah di Indonesia. PT. Gramedia. Jakarta.

Devas, N.B.B., Booth, A., Davey, K., \& Kelley, R. (1989). Keuangan Pemerintah Daerah di Indonesia. UI-Press. Jakarta.

Irwan, T.R. (2009) Perencanaan dan Penganggaran Keuangan Daerah di Indonesia. Program Pascasarjana UGM,Yogyakarta.

Gei, N. (1968). Otonomi dan Desentralisasi Keuangan Daerah. Prisma No.8 LPES, Jakarta.

Harun. (2010). Menghitung Potensi Pajak dan Retribusi Daerah. Universitas Janabadra, Yogyakarta.

Insukindro., Mardiasmo., Widayat, W.K., Purwanto, B.M., Halim, A., \& Purnomo, A.B. (1994). Peranan dan Pengelolaan Keuangan Daerah dalam usaha Peningkatan $P A D$. Kursus Keuangan Daerah, FE-UGM.

Jamil, A., \& Rahayu, A. (1997). Analisis Pajak Pembangunan Perhotelan Sebagai Sumber Pendapatan Asli Daerah, Studi Kasus Kabupaten Sarolangun. JEP, 3(3),312-323.

Kho,Y.R. (1997). Prospek Otonomi Daerah di Negara Republik Indonesia, Identifikasi beberapa faktor yang mempengaruhi penyelenggaraan. Grafindo Persara, Jakarta. 
Mardiasmo. (2003). Perpajakan edisi Revisi, Andi Publisher.

Peraturan Daerah No.2 Tahun 2004. Tentang Pajak Reklame di Sarolangun.

Peraturan Daerah No.15 Tahun 2010. Tentang Pajak Reklame di Wilayah Kabupaten Sarolangun.

Prakoso, K.B. (2003). Pajak dan Retribusi Daerah. UII Press.Yogyakarta.

Rochmad, S. (2008). Peradilan admministrasi dalam hukum pajak di Indonesia. Pusat Pengkajian Fiskal dan Moneter. University of California.

Ronny, H.H., Modesta. (2011). Analisis Peranan Pajak Reklame dalam meningkatkan Kontribusi Pendapatan Asli Daerah di Kabupaten Malang (Studi Kasus Pada Dinas Pendapatan, Pengelolaan Keuangan dan Aset Kabupaten Malang). Jurnal Ekonomi dan Manajemen, 12(1).

Siahaan. (20050. Pajak Daerah dan Retribusi Daerah. Raja Grafindo Persada.

Rahayu, S.K., \& Suhayati, E. (2010). Perpajakan Teori dan Teknis Perhitungan. Graha Ilmu. Yogyakarta.

Soeratno., \& Arsyad, L. (1999). Metodologi Penelitian untuk Ekonomi dan Bisnis, Edisi Revisi. AMP YKPN, Yogyakarta.

Suparmoko, M. (1992). Azas-azas Keuangan Daerah, Edisi Revisi. Rineka Cipta. Jakarta. . (2001). Ekonomi Pupblik untuk Keuangan dan Pembangunan Daerah. FE-UGM. Yogyakarta.

Syamsi, I. (1998). Dasar-dasar Ilmu Keuangan Negara, Cetakan Ketiga. BP-FEUGM,Yogyakarta.

Teguh Y.W. (2008). Manajemen otonomi daerah berdasarkan paradigma baru. CloGAPPS, Universitas Diponegoro.

Undang-Undang Republik Indonesia No.25 Tahun 1999 tentang perimbangan keuangan pusat dan daerah.

Undang-Undang Republik Indonesia No.34 Tahun 2000 tentang pajak daerah dan retribusi daerah.

Undang-Undang Republik Indonesia Nomor 33 Tahun 2004 tentang Perimbangan Keuangan Antara Pusat dan Daerah.

Undang-Undang Republik Indonesia No.28 Tahun 2007, tentang ketentuan umum dan tata cara perpajakan. 
Undang-Undang Republik Indonesia No.28 Tahun 2009, tentang pajak daerah dan retribusi daerah. 